\title{
Biochemical and Physical Analyses of Newly Synthesized Muscarinic Acetylcholine Receptors in Cultured Embryonic Chicken Cardiac Cells
}

\author{
Dale D. Hunter ${ }^{1}$ and Neil M. Nathanson \\ Department of Pharmacology, University of Washington, Seattle, Washington 98195
}

Exposure of cultured embryonic chicken cardiac cells to the muscarinic agonist carbachol results in a $70-80 \%$ decrease in the number of muscarinic acetylcholine receptors $(\mathrm{mAChR})$ expressed on the surface of the cells. Removal of the agonist results in a gradual increase in mAChR number because of the accumulation of newly synthesized receptors, reaching the control level in $14 \mathrm{hr}$. Measurements of increases in $\mathrm{K}^{+}$permeability elicited by carbachol show that even after the complete recovery of receptor number, the sensitivity to agonist is reduced. The $\mathrm{EC}_{50}$ for carbachol is 13-fold higher in cells that have been exposed to carbachol and allowed to recover for $18 \mathrm{hr}$ than in control cells, but is not significantly different from the $\mathrm{EC}_{50}$ for control cells $24 \mathrm{hr}$ after agonist removal. The sensitivity of the mAChR-mediated inhibition of adenylate cyclase is also decreased at $18 \mathrm{hr}$, and recovers by $24 \mathrm{hr}$. These increases in sensitivity of $\mathrm{mAChR}$-mediated responses are not blocked by administration of cycloheximide, and thus do not require de novo protein synthesis.

The number of surface $\mathrm{mAChR}$ available for ligand binding can be reduced by $85-100 \%$ by treatment with the affinity-alkylating antagonist propylbenzilylcholine mustard. Newly synthesized $\mathrm{mAChR}$ that appear following affinity alkylation are also poorly coupled to $m A C h R-m e d i a t e d$ increases in $K^{+}$permeability, indicating that decreased physiological sensitivity is not due to a nonspecific effect of long-term agonist exposure on general cellular function, but reflects, rather, an intrinsic property of newly synthesized $\mathrm{mAChR}$.

The decrease in sensitivity of the $\mathrm{mAChR}$-mediated responses is due neither to a lack of expression of $\mathrm{mAChR}$ on the surface nor to reduced agonist affinity of the $\mathrm{mAChR}$. Cells exhibiting decreased responsiveness contain GTP-binding proteins, which function normally in the inhibition of adenylate cyclase and appear to be identical to pertussis toxin substrates from control cells using gel electrophoresis; therefore, the decreased sensitivity does not appear to be the result of an alteration in coupling proteins. These cells also contain $\mathrm{mAChR}$ that do not differ from those in control cells either by molecular weight or isoelectric point. Thus, the diminished sensitivity observed in cells containing newly synthesized receptors is either caused by a small change in $\mathrm{mAChR}$ not detected by these electrophoretic

Received Mar. 31, 1986; revised June 24, 1986; accepted July 1, 1986.

This work was supported by a Grant-in-Aid from the American Heart Association with funds contributed in part by the American Heart Association of Washington, and by NIH Grant HL 30639 and Training Grants T32 GM 0775004 and 2 T32 HL 07312-07. N.M.N. is an Established Investigator of the American Heart Association.

Correspondence should be addressed to Neil M. Nathanson, Department of Pharmacology SJ-30, University of Washington, Seattle, WA 98195.

' Present address: Dept. of Anatomy and Neurobiology, Washington University School of Medicine, St. Louis, MO 63110.

Copyright (C) 1986 Society for Neuroscience $0270-6474 / 86 / 123739-10 \$ 02.00 / 0$ techniques or by a change in an as-yet-undefined component of the $\mathrm{mAChR}$ transduction system in the heart.

Treatment of cultured heart, neuroblastoma, and neuroblastoma-glioma hybrid cells with muscarinic agonists results in a dose- and time-dependent decrease in the number of muscarinic acetylcholine receptors (mAChR) expressed in those cells (Galper and Smith, 1980; Klein et al., 1979; Shifrin and Klein, 1980). This decrease is probably due to an increase in the rate of receptor internalization and breakdown (Galper et al., 1982a; Klein et al., 1979; Shifrin and Klein, 1980); the appearance of $\mathrm{mAChR}$ in a light vesicle fraction following agonist exposure in astrocytoma cells (Harden et al., 1985) is consistent with this hypothesis. Removal of the agonist following decreases in $\mathrm{mAChR}$ number results in a gradual increase in $\mathrm{MAChR}$ number to the control level; this increase can be blocked by treatment with protein synthesis inhibitors such as cycloheximide (Galper and Smith, 1980; Klein et al., 1979), or by inhibition of protein glycosylation (Liles and Nathanson, 1986), which suggests that $\mathrm{mAChR}$ that appear following agonist-induced receptor loss are newly synthesized receptor proteins.

Treatment of chicken embryos in ovo with muscarinic agonists also leads to a dose- and time-dependent decrease in mAChR number in the heart (Halvorsen and Nathanson, 1981) and the brain (Meyer et al., 1982). Reduction of mAChR number in the heart by treatment with the muscarinic agonist carbachol is accompanied by a shift in the concentration-effect curve for the $\mathrm{mAChR}$-mediated negative chronotropic response in isolated atria (Halvorsen and Nathanson, 1981). Subsequent block of the agonist-receptor interaction by administration of the muscarinic antagonist atropine results in a gradual increase in receptor number, with a time course similar to that observed in cell culture; this increase is also blocked by administration of cycloheximide (Hunter and Nathanson, 1984).

Previous work (Hunter and Nathanson, 1984) has shown that the receptors that reappear following agonist-induced receptor loss in ovo are poorly coupled to several $\mathrm{mAChR}$-mediated responses, including the inhibition of adenylate cyclase and the negative chronotropic response. The sensitivity of both responses increased even in the presence of cycloheximide, suggesting that $\mathrm{mAChR}$ may be initially synthesized in a less active form.

The studies reported here describe physiological and biochemical properties of newly synthesized $\mathrm{mAChR}$ in cardiac cell culture. This system offers several advantages compared to the in vivo system used for previous work on newly synthesized $\mathrm{mAChR}$. Cell culture allows for direct quantitation of receptor recovery on the cell surface, as opposed to the determination of total cellular receptor number in atrial membrane homogenates. It is therefore possible to ensure that the decreased sensitivity to muscarinic agonists is not due to the accumulation of intraccllular reccptors not cxpressed on the ccll surface. The 
system also allows a more direct investigation of the regulation of potassium permeability by $\mathrm{mAChR}$, using the $\mathrm{mAChR}$-mediated stimulation of $\mathrm{Rb}^{+}$efflux. Previous work (Galper et al., $1982 \mathrm{~b}$ ) suggested that the stimulation of $\mathrm{K}^{+}$efflux recovered with the same time course as that of $\mathrm{mAChR}$ number in vitro, which is inconsistent with the decreased sensitivity of the negative chronotropic response observed following recovery of $\mathrm{mAChR}$ number after agonist-induced decreases in vivo. The work of Galper et al. (1982b), however, used only a single, saturating concentration of carbachol to elicit the response. We therefore wanted to examine the recovery of sensitivity for mAChR-mediated increases in $K^{\prime}$ permeability in cell culture in greater detail.

The use of an in vitro system also allowed for several types of studies not possible in vivo. In order to ensure that the decreased sensitivity seen in cells containing newly synthesized $\mathrm{mAChR}$ was not the result of an unknown or nonspecific effect of long-term exposure to agonist, we used the affinity-alkylating agent propylbenzilylcholine mustard (PrBCM) to eliminate agonist binding sites, then examined the reappearance of binding sites and recovery of responsiveness to muscarinic agonists. We were also able to label $\mathrm{MAChR}$ in situ with ${ }^{3} \mathrm{H}-\mathrm{PrBCM}$, thus allowing for investigation of physical properties of $\mathrm{mAChR}$ without the need for homogenization, which can produce artifacts from such factors as endogenous proteases and phosphatases.

The results reported herc show that reccptors that reappcar following both agonist-induced receptor loss and alkylation of existing receptor binding sites are poorly coupled to the stimulation of $\mathbf{R b}^{+}$efflux. This decreased sensitivity is not due to either a lack of expression of the receptor on the cell surface nor to a decreased affinity of the newly synthesized receptor for muscarinic agonists. The sensitivity of the response recovers even in the presence of cycloheximide, suggesting that $\mathrm{mAChR}$, or closely linked proteins, is initially synthesized in an "immature" form that is subsequently converted to a more active form.

\section{Materials and Methods}

\section{Materials}

White Leghorn chicken embryos were obtained locally from College Biologicals (Bothell, WA) and maintained at $38^{\circ} \mathrm{C}$ in a humidified incubator. Dissections were performed on the ninth incubation day.

Ampholytes for isuelectric focusing were from Bio-Rad, LKB, or Pharmacia. Cation exchange resin was from Bio-Rad (AG50W-X4). ${ }^{3} \mathrm{H}$-Quinuclidinyl benzilate $\left({ }^{3} \mathrm{H}-\mathrm{QNB}\right.$; specific activity $27 \mathrm{Ci} / \mathrm{mmol}$ ), $\alpha-{ }^{32} \mathrm{P}-\mathrm{ATP}$ (specific activity $30-50 \mathrm{Ci} / \mathrm{mmol}$ ), ${ }^{80} \mathrm{RbCl}$ (specific activity $750 \mathrm{Ci} / \mathrm{mol}$ ), ${ }^{3} \mathrm{H}$-leucine (specific activity $50 \mathrm{Ci} / \mathrm{mmol}$ ), and ${ }^{3} \mathrm{H}$-propylbenzilylcholine mustard ( ${ }^{3} \mathrm{H}-\mathrm{PrBCM}$; specific activity $\left.40-60 \mathrm{Ci} / \mathrm{mmol}\right)$ were from New England Nuclear. ${ }^{3} \mathrm{H}$-cAMP (specific activity $27 \mathrm{Ci}$ / $\mathrm{mmol}$ ) and ${ }^{3} \mathrm{H}$-leucine (specific activity $50-60 \mathrm{Ci} / \mathrm{mmol}$ ) were from ICN. ${ }^{3} \mathrm{H}-\mathrm{QNB}$ (specific activity $\left.36 \mathrm{Ci} / \mathrm{mmol}\right),{ }^{3} \mathrm{H}-\mathrm{N}$-methyl scopolamine $\left({ }^{3} \mathrm{H}-\right.$ NMS; specific activity $80 \mathrm{Ci} / \mathrm{mmol}$ ), and PrBCM (unlabeled) were from Amersham-Searle.

Medium-199, fetal bovine serum, and penicillin-streptomycin were from Gibco. Fetal bovine serum (defined) was from Hyclone.

Other materials were from previously described sources (Halvorsen and Nathanson, 1984).

\section{Methods}

Embryonic heart cell cultures. Embryonic chicken cardiac cell monolayers were prepared from whole $9 \mathrm{~d}$ embryonic hearts by the method of DeHaen (1967), as previously modified (Nathanson, 1983). Cells were dispersed by sequential trypsin treatments of whole $9 \mathrm{~d}$ hearts, plated to remove fibroblasts, then seeded into collagen-coated tissue culture plates in a growth medium consisting of $47 \%$ Medium- $199,47 \%$ potassium-free Earle's salts $\left(118 \mathrm{~mm} \mathrm{NaCl}, 1.8 \mathrm{~mm} \mathrm{CaCl}_{2}, 0.8 \mathrm{mM} \mathrm{MgSO}\right.$, $1 \mathrm{~mm} \mathrm{NaH} \mathrm{PO}_{4}, 1.0 \mathrm{gm} /$ liter $d$-glucose, and $25 \mathrm{~mm} \mathrm{NaHCO}, \mathrm{pH} 7.4$ ), $1 \%$ penicillin-streptomycin (final concentrations, $100 \mathrm{U} / \mathrm{ml}$ and $100 \mu \mathrm{g} /$ $\mathrm{ml}$, respectively), and $5 \%$ fetal bovine serum, and maintained in a humidified $95 \%$ air $/ 5 \% \mathrm{CO}_{2}$ incubator. The density of plating was as follows: $2 \times 10^{5}$ cells $/ 16-\mathrm{mm}$-diameter well; $0.95 \times 10^{6} \mathrm{cells} / 35 \mathrm{~mm}$ plate; $7.4 \times 10^{6} \mathrm{cells} / 100 \mathrm{~mm}$ plate. Since initial studies demonstrated that growth of cells in different lots of fetal bovine serum results in large variations in the sensitivity and maximum responsiveness to muscarinic agonists in the adenylate cyclase and $\mathrm{Rb}^{+}$flux assays (for example, compare the control carbachol concentration-effect curves in Figs. 3 and 10), individual samples of serum lots were screened for the ability to maintain physiological responses; lots in which cells showed poor or inconsistent responses were rejected. Gibco lots 27P4320 and 27N2732 were used for the adenylate cyclase assays, and Gibco lots 27N2732 and $31 \mathrm{~K} 8843$ and Hyclone lot 1114574 were used for the $\mathrm{Rb}^{+}$flux assays. These lots gave the most consistent results. The medium was changed on the third day in culture, at which time the cells had formed a confluent monolayer.

Administration of drugs. Drugs were administered either by direct addition to growth medium or by changing growth medium for medium containing the drug. Drugs were removed by aspiration of medium and washed 3 times with warm $\left(37^{\circ} \mathrm{C}\right)$ medium.

Preparation of membrane homogenates. Cultured cells were washed free of growth medium with Earle's salts, then homogenized on ice with 20 strokes of a ground-glass homogenizer in the appropriate hypotonic buffer (see below). Homogenates were centrifuged at $4^{\circ} \mathrm{C}$ at $15,000 \times g$ for $15 \mathrm{~min}$, washed twice (by centrifugation) with ice-cold buffer, and resuspended in the appropriate assay buffer (see below).

Assay for $m A C h R$. The binding of the highly specific muscarinic antagonists ${ }^{3} \mathrm{H}-\mathrm{QNB}$ and ${ }^{3} \mathrm{H}-\mathrm{NMS}$ in membrane homogenates was carried out by using a modification of the filter-binding technique of Yamamura and Snyder (1974) as previously described (Halvorsen and Nathanson, 1981). The binding of ${ }^{3} \mathrm{H}$-antagonists to intact cells was carried out by the method of Nathanson (1983). The density of mAChR in homogenates is expressed as $\mathrm{fmol}^{3} \mathrm{H}$-antagonist bound $/ \mathrm{mg}$ membrane protein, and for intact cells as fmol ${ }^{3} \mathrm{H}$-antagonist bound $/ 35 \mathrm{~mm}$ plate; in both cases, nonspecific binding, as determined by the binding of ${ }^{3} \mathrm{H}$-antagonist in the presence of $1 \mu \mathrm{M}$ atropine, was subtracted from total binding to give specific binding. Protein content was determined by a modification (Halvorsen and Nathanson, 1981) of the method of Lowry et al. (1951). Binding of carbachol to $\mathrm{mAChR}$ in membrane homogenates was measured by the ability of increasing concentrations of the agonist to inhibit the binding of $0.33 \mathrm{nM}{ }^{3} \mathrm{H}-\mathrm{QNB}$.

Determination of inhibition of protein synthesis. The inhibition of protein synthesis was determined by the ability of cycloheximide to inhibit the incorporation of ${ }^{3} \mathrm{H}$-leucine $(2 \mu \mathrm{Ci} / \mathrm{ml})$ into cardiac cell monolayers. The addition of $20 \mu \mathrm{M}$ cycloheximide blocked $>90 \%$ of protein synthesis.

Assay of ${ }^{86} R b^{+}$flux. Efflux of ${ }^{86} \mathrm{Rb}^{+}$from cultured cardiac monolayers was determined as described by Hunter and Nathanson (1985).

Adenylate cyclase assay. Cells were homogenized and resuspended in

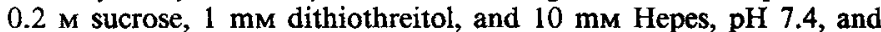
adenylate cyclase activity in these homogenates was determined as previously described (Hunter and Nathanson, 1984). Basal activity generated was approximately $100 \mathrm{pmol} \mathrm{cAMP} / 10 \mathrm{~min} / \mathrm{mg}$ membrane protein; activity in the presence of $1 \mu \mathrm{M} \mathrm{GTP}$ and $10 \mu \mathrm{M} l$-isoproterenol was approximately $500 \mathrm{pmol} / 10 \mathrm{~min} / \mathrm{mg}$.

$A D P$ ribosylation of membrane proteins. Cells were homogenized and resuspended in $100 \mathrm{~mm}$ Tris- $\mathrm{HCl}, \mathrm{pH} 8.0$, and the homogenates were labeled in the presence of ${ }^{32}$ P-NAD (nicotinamide adenine dinucleotide) and pertussis toxin, as previously described (Halvorsen and Nathanson, 1984).

Preparation of ADP-ribosylated proteins for electrophoresis. For SDSgel electrophoresis, ADP-ribosylated membranes were solubilized in SDS sample buffer (3.5\% SDS, 5\% 2-mercaptoethanol, $10 \%$ glycerol, $0.0005 \%$ bromophenol blue, and $125 \mathrm{~mm}$ Tris- $\mathrm{HCl}, \mathrm{pH} 6.8$ ) and heated at $100^{\circ} \mathrm{C}$ for $2 \mathrm{~min}$. For isoelectric focusing, ADP-ribosylated membranes were solubilized in half-strength SDS sample buffer, heated at $100^{\circ} \mathrm{C}$ for $2 \mathrm{~min}$, and cooled to room temperature; urea was then added to $9.5 \mathrm{M}$ and 2 volumes of sample dilution buffer [9.5 $\mathrm{M}$ urea, $5 \%$ 2-mercaptoethanol, $8 \%$ Nonidet P-40 (NP-40), and 3\% ampholytes (consisting of 20\% 3-10, 40\% 4-6, and 40\% 5-7)] was added, as described by $\Lambda$ mes and Nikaido (1976).

$S D S$-gel electrophoresis of ADP-ribosylated proteins. ADP-ribosylated samples were electrophoresed by a modification (Nathanson and Hall, 1979) of the method of Laemmli (1970). Proteins used as molec- 

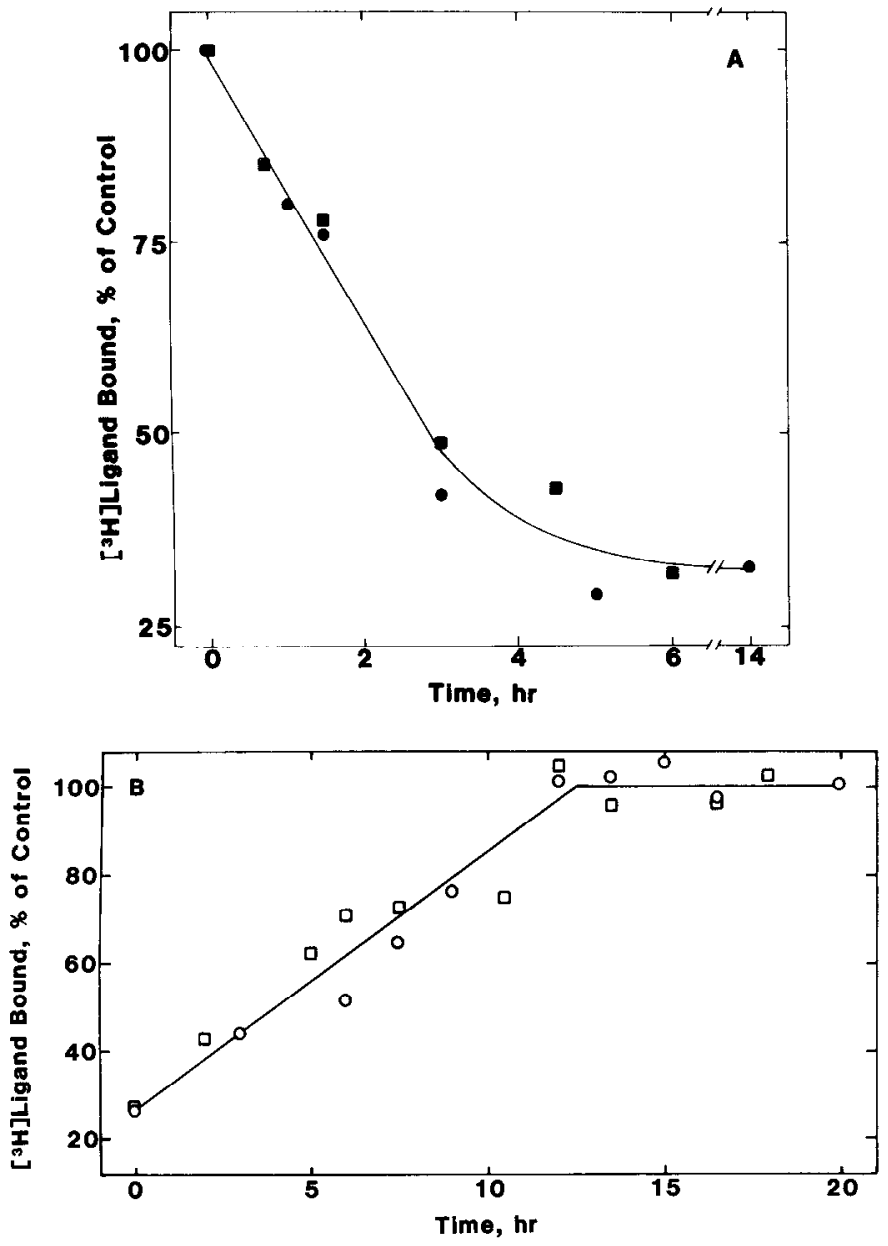

Figure 1. Time courses of receptor decrease following agonist exposure and receptor recovery after agonist removal. $A$, Cardiac cells in $35 \mathrm{~mm}$ dishes were treated with $1 \mathrm{mM}$ carbachol for the times shown, after which receptor number was determined, as described in Methods. $B$, Cardiac cells in $35 \mathrm{~mm}$ dishes were treated with $1 \mathrm{~mm}$ carbachol for 6 $\mathrm{hr}$, washed, and allowed to recover for the times shown, after which receptor number was determined, as described in Methods. $(\mathbf{O}),(\mathrm{O}),{ }^{3} \mathrm{H}$ -

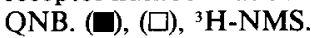

ular weight standards were $\beta$-galactosidase $(116,000)$, bovine serum albumin $(68,000)$, pyruvate kinase $(57,000)$, fumarase $(49,000)$, aldolase $(40,000)$, and glyceraldehyde-3-phosphate dehydrogenase $(36,000)$. Gels were dried and then autoradiographed by exposure to Kodak X-Omat film at $-80^{\circ} \mathrm{C}$ using a Cronex intensifying screen.

Two-dimensional electrophoresis. Two-dimensional electrophoresis of ADP-ribosylated proteins was performed by a modification (Halvorsen and Nathanson, 1984) of the method of Ames and Nikaido (1976).

${ }^{3} H$-PrBCM labeling of intact cells. Cells grown in $100 \mathrm{~mm}$ tissue culture dishes were washed free of growth medium with $37^{\circ} \mathrm{C}$ Earle's salts, then $6 \mathrm{ml}$ of $37^{\circ} \mathrm{C}$ Earle's salts was added. Atropine was then added to plates used for nonspecific labeling at a final concentration of $10 \mu \mathrm{M}$, and the plates were incubated for $15 \mathrm{~min}$ in a humidified incubator at $37^{\circ} \mathrm{C}$. Cyclized ${ }^{3} \mathrm{H}-\mathrm{PrBCM}$ (PrBCM was cyclized by diluting a small

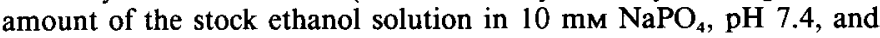
incubating at $20^{\circ} \mathrm{C}$ for $30-60 \mathrm{~min}$ ) was then added at a final concentration of 2-5 nM, and the plates incubated for $20 \mathrm{~min}$. Reactions were terminated by aspiration and washing 3 times with ice-cold Earle's salts, and immediate solubilization in the appropriate buffer on ice.

Preparation of $\operatorname{PrBCM}$-labeled proteins for electrophoresis. For SDSgel electrophoresis, intact cells were solubilized in SDS-urea sample buffer (3.5\% SDS, 5\% 2-mercaptoethanol, $10 \%$ glycerol, $0.0005 \%$ bromophenol blue, $8 \mathrm{~m}$ urea, and $125 \mathrm{~mm}$ Tris- $\mathrm{HCl}, \mathrm{pH} 6.8$; this was made

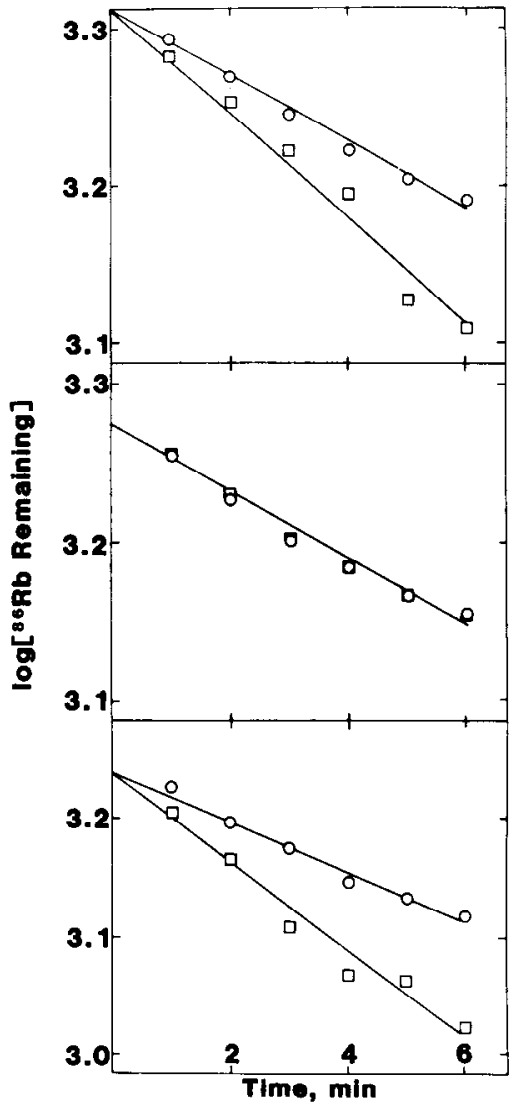

Figure 2. Stimulation of $\mathrm{Rb}^{+}$efflux by carbachol. Cells were cultured in Gibco fetal bovine serum, lot 27N2732. Top, Control. At $t=0$, fresh medium was added with no addition $(O)$, or with $0.1 \mu \mathrm{M}$ carbachol $(\square)$. Correlation coefficients for these lines were 0.994 and 0.992. Center, Cells were treated with $1 \mathrm{~mm}$ carbachol for $6 \mathrm{hr}$ at $37^{\circ} \mathrm{C}$, washed, and allowed to recover for $18 \mathrm{hr}$. At $t=0$, fresh medium was added with no addition $(O)$, or with $0.1 \mu \mathrm{M}$ carbachol ( $\square$ ). Correlation coefficients for these lines were 0.986 and 0.987 . Bottom, Cells were treated with $1 \mathrm{~mm}$ carbachol for $6 \mathrm{hr}$ at $37^{\circ} \mathrm{C}$, washed, and allowed to recover for $24 \mathrm{hr}$. At $t=0$, fresh medium was added with no addition (O), or with $0.1 \mu \mathrm{M}$ carbachol ( $\square$ ). Correlation coefficients for these lines were 0.986 and 0.981 .

fresh using a $5 \times$ concentrated stock of SDS sample buffer without urea). For isoelectric focusing, intact cells were directly solubilized in a buffer consisting of $6.7 \%$ glycerol, $3 \% \mathrm{NP}-40,6.3 \mathrm{~m}$ urea, $3.3 \% 2$-mercaptoethanol, $1.3 \%$ ampholytes $(26.6 \% 3-10,53.4 \% 4-6$, and $20 \% 5-7)$, and $33 \mathrm{mM} \mathrm{NaPO}_{4}, \mathrm{pH} 7.4$. We have found it extremely important to solubilize the cells directly, instead of solubilizing membrane homogenates. Treatment of membrane homogenates with ${ }^{3} \mathrm{H}-\mathrm{PrBCM}$ results in the labeling of a polypeptide of lower molecular weight than that seen after direct solubilization of cells treated with ${ }^{3} \mathrm{H}-\mathrm{PrBCM}$. Inclusion of a wide variety of protease inhibitors (Halvorsen and Nathanson, 1984) did not prevent this conversion, which is not a property of the membranes themselves, since mixing these labeled membranes with labeled membranes that do not show a conversion of the receptor to the lower molecular weight (bovine brain cortex) resulted in 2 labeled polypeptides, identical to the 2 seen in the individual labeled membrane preparations. It is intriguing that this lower-molecular-weight (ca. 48,000) protein remains associated with the membrane, is capable of binding agonists and antagonists, and can inhibit adenylate cyclase. We assume that its production is due to a proteolytic degradation, but we cannot rule out the role of such processes as deglycosylation.

SDS-gel electrophoresis of PrBCM-labeled proteins. Since mAChR had a tendency not to enter the running gel using SDS alone, we used a SDS-urea gel system. The presence of $4 \mathrm{~m}$ urea in the gel and $8 \mathrm{M}$ urea in the sample greatly enhanced the solubility of $\mathrm{mAChR}$, allowing nearly all of the receptor to enter the gel (Fig. 11). Except for the inclusion 

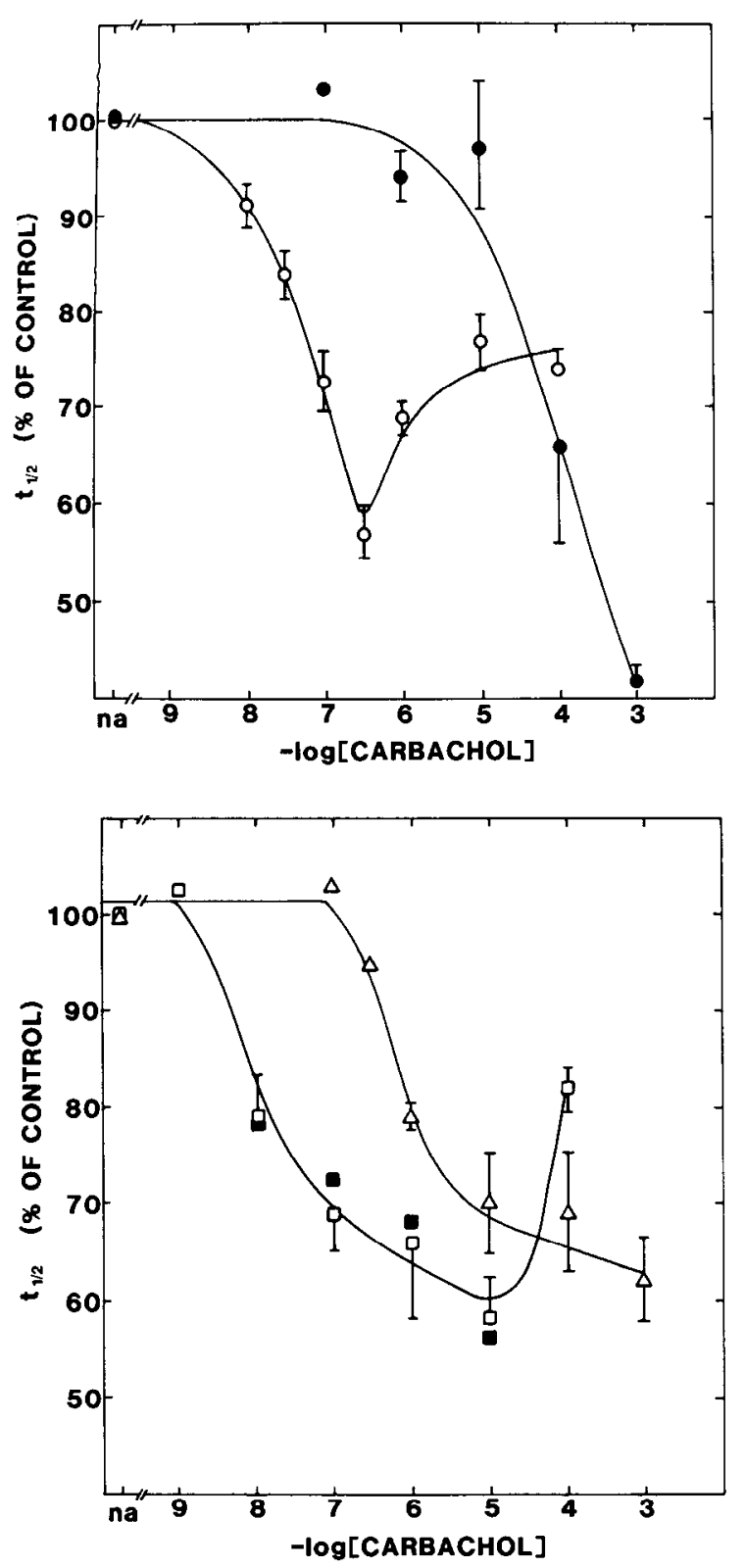

Figure 3. Concentration-effect curves for carbachol-mediated stimulation of $\mathrm{Rb}^{+}$efflux. Increasing concentrations of carbachol were added to triplicate $16 \mathrm{~mm}$ wells at $t=0$, and half-times of efflux were determined as described in Methods. Cells were cultured in Gibco fetal bovine serum, lot 27N2732. Top, Concentration-effect curves for control cells $(O)$ and cells treated with $1 \mathrm{~mm}$ carbachol for $6 \mathrm{hr}(\bullet)$. Bottom, Concentration-effect curves for $18 \mathrm{hr}$ recovered cells $(\triangle), 24 \mathrm{hr}$ recovered cells $(\square)$, and cells that recovered for $18 \mathrm{hr}$ were treated with $20 \mu \mathrm{M}$ cycloheximide, and allowed to recover for an additional $6 \mathrm{hr}(\square)$. Error bars show the SEM for at least 4 independent experiments in each case. $n a$, No addition.

of urea, electrophoresis was performed as for ADP-ribosylated samples. Gels were sliced and the slices dissolved by heating in $30 \% \mathrm{H}_{2} \mathrm{O}_{2}$ for at least $2 \mathrm{hr}$ at $80^{\circ} \mathrm{C}$. Scintillation fluid was then added for determination of radioactivity in the dissolved slices.

Isoelectric focusing. Initial attempts at isoelectric focusing of $\mathrm{mAChR}$ by conventional methods were unsuccessful; this was largely due to the tendency of the mAChR to aggregate in most detergent solutions (cven SDS; see above), and thus to not enter the gel. Vlasuk and Walz (1980) encountered a similar problem when attempting to focus liver endoplasmic reticulum proteins; we therefore used a modification of their method, which uses a Triton X-100-urea isoelectric focusing system,

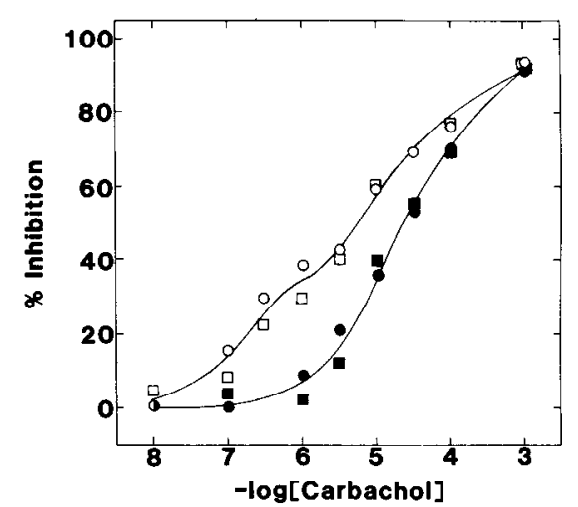

Figure 4. Competition of ${ }^{3} \mathrm{H}-\mathrm{QNB}$ binding by carbachol. Cells grown in $100 \mathrm{~mm}$ dishes were scraped, homogenized, and assayed for the ability of carbachol to compete for ${ }^{3} \mathrm{H}-\mathrm{QNB}$ binding, as described in Methods. Results are the average of 2 separate experiments, each done in duplicate, with SE generally $<10 \%$. (O), Control; $(\square), 18 \mathrm{hr}$ recovered. Open symbols, in the absence of GppNHp; closed symbols, in the presence of $10 \mu \mathrm{M} \mathrm{GppNHp}$.

and involves application of the sample to the acidic end of the gel. Briefly, intact cells were solubilized in an NP-40-urea-ampholyte-glycerol- $\mathrm{PO}_{4}$ buffer (see Preparation of $\mathrm{PrBCM}$-labeled proteins for electrophoresis, above). This solution was saturated with urea and the $\mathrm{pH}$ was adjusted to ca. 4.0 with $\mathrm{HCl}$. The sample was then applied to the acidic end of the focusing gel and focused for $>8000 \mathrm{~V} \cdot \mathrm{hr}$. A large percentage of $\mathrm{mAChR}$ entered the gel using these conditions (see Fig. 12). Gels were sliced, dissolved in $30 \% \mathrm{H}_{2} \mathrm{O}_{2}$, and counted.

\section{Results}

Time course of receptor decrease and recovery following agonist exposure

Incubation of cultured cardiac cells with $1 \mathrm{~mm}$ carbachol resulted in a $70 \%$ reduction in $\mathrm{MAChR}$ expressed on the surface of the cells (determined by specific binding of the hydrophilic antagonist ${ }^{3} \mathrm{H}-\mathrm{NMS}$ ) within $6 \mathrm{hr}$ (Fig. $1 A$ ). The reduction in total $\mathrm{mAChR}$ number, determined by the binding of ${ }^{3} \mathrm{H}-\mathrm{QNB}$, paralleled the reduction in surface number. This is consistent with previous work (Galper et al., 1982a; Klein et al., 1979; Shifrin and Klein, 1980) that demonstrated that decreases in receptor number following long-term agonist exposure are due to increased degradation of $\mathrm{mAChR}$. Removal of agonist resulted in a gradual increase in receptor number, reaching the control level at $14 \mathrm{hr}$ after agonist removal (Fig. $1 B$ ). Surface receptor number recovered with an identical time course as total receptor number, indicating that there is not a significant pool of internal receptors in transit to the surface. This increase in $\mathrm{mAChR}$ number is blocked by incubation with $20 \mu \mathrm{M}$ cycloheximide (not shown), in agreement with results reported both in vitro (Galper and Smith, 1980; Klein et al., 1979) and in vivo (Hunter and Nathanson, 1984); the block of receptor recovery with cycloheximide is consistent with suggestions that the mAChR that appear following agonist-induced decreases represent newly synthesized receptor molecules.

\section{Responsiveness of cardiac cells containing newly synthesized $m A C h R$}

To determine the ability of cardiac cells containing newly synthesized receptors to respond to applied carbachol, we measured the stimulation of $\mathrm{Rb}^{+}$efflux in response to muscarinic agonists. This response has been characterized previously in this laboratory (Hunter and Nathanson, 1985), and has been shown to reflect increases in $\mathrm{K}^{+}$permeability. In the cardiac sino-atrial node and in atria, increases in $\mathrm{K}^{+}$permeability underlie the 


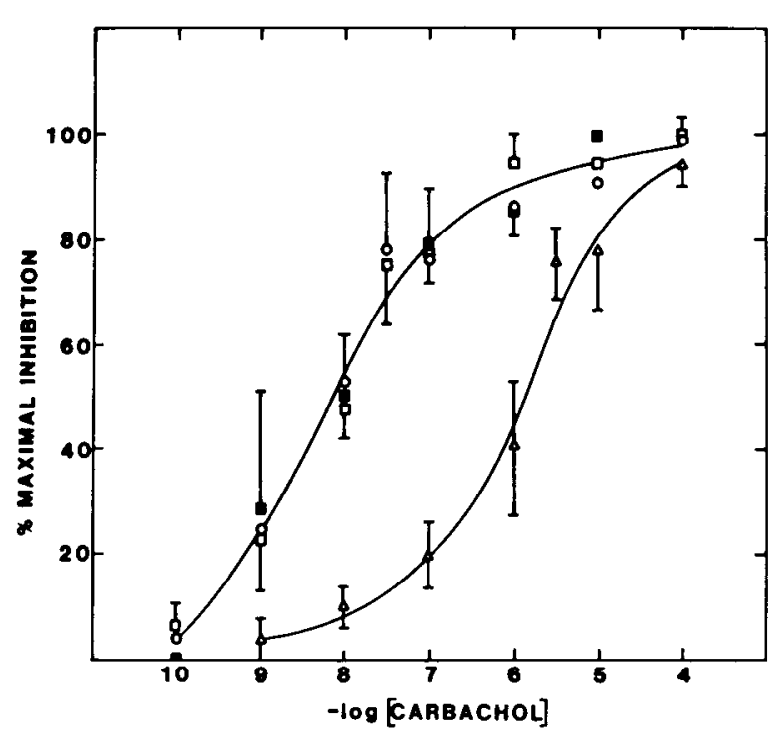

Figure 5. Inhibition of adenylate cyclase by carbachol. Homogenates of cells grown in $100 \mathrm{~mm}$ dishes were assayed for the inhibition of adenylate cyclase by increasing concentration of carbachol in the presence of $1 \mu \mathrm{M}$ GTP and $10 \mu \mathrm{M}$ isoproterenol, as described in Methods. $(O)$, Control; $(\triangle), 18 \mathrm{hr}$ recovered; $(\square), 24 \mathrm{hr}$ recovered; $(\square)$, cells that were allowed to recover for $18 \mathrm{hr}$, wcrc treated with $20 \mu \mathrm{M}$ cycloheximide, then allowed to recover for an additional $6 \mathrm{hr}$. Error bars show the SEM for at least 3 experiments in each case.

negative chronotropic response to muscarinic agonists (Inoue et al., 1983; Sakmann et al., 1983; Trautwein and Dudel, 1958).

The response of cardiac cells following treatment with and washout of agonist for various times is compared to the response in control cells in Figures 2 and 3. Representative control wells are shown in Figure 2 (top); in the presence of $0.1 \mu \mathrm{M}$ carbachol, the $t_{1 / 2}$ for efflux decreased from 13.9 to $8.2 \mathrm{~min}$. Figure 3 (top) shows a concentration-effect curve for the stimulation of $\mathrm{Rb}^{+}$ efflux in control cells and in cells following exposure to $1 \mathrm{mM}$ carbachol for $6 \mathrm{hr}$. Control cells respond with a reduction in $t_{1 / 2}$ of $43 \%$ and with an $\mathrm{EC}_{50}$ of $64 \pm 28 \mathrm{nM}$ (mean $\pm \mathrm{SEM}$ ), whereas cardiac cells exposed to agonist (resulting in a loss of $78 \%$ of $\mathrm{mAChR}$ number) respond with a reduction in $t_{1 / 2}$ of $59 \%$, with an $\mathrm{EC}_{50}$ of $65 \pm 25 \mu \mathrm{M}$ (significantly different from control; $p<$ 0.01 ). This is in agreement with previously published reports showing diminished sensitivity, without a decrease in maximal response, in cells (Hunter and Nathanson, 1985) and atria (Halvorsen and Nathanson, 1981) containing reduced levels of $\mathrm{mAChR}$, and is consistent with the presence of a large spare receptor reserve for the stimulation of increases in potassium permeability under these particular culture conditions.

The responses of representative cells containing newly synthesized $\mathrm{mAChR}$ are shown in Figure 2, center and bottom sections. For cells treated with carbachol for $6 \mathrm{hr}$, and allowed to recover for $18 \mathrm{hr}$ (" $18 \mathrm{hr}$ recovered"; mAChR number is $100 \%$ of control by this time; Fig. $1 B$ ), the $t_{1 / 2}$ for efflux increased from 13.7 to $14.1 \mathrm{~min}$ in the presence of $0.1 \mu \mathrm{M}$ carbachol (Fig. 2 , center). This concentration of carbachol thus did not elicit an increase in ${ }^{86} \mathrm{Rb}^{+}$efflux. For cells treated with carbachol for $6 \mathrm{hr}$, then allowed to recover for $24 \mathrm{hr}$ (" $24 \mathrm{hr}$ recovered"), the $t_{1 / 2}$ for efflux decreased from 12.8 to $7.7 \mathrm{~min}$ in the presence of $0.1 \mu \mathrm{M}$ carbachol (Fig. 2, bottom); this responsc was similar to that seen in control cells (Fig. 2, top).

Figure 3 (bottom) shows the concentration-effect curves for cells that were treated with $1 \mathrm{~mm}$ carbachol for $6 \mathrm{hr}$, washed, and allowed to recover for 18 or $24 \mathrm{hr}$; " $18 \mathrm{hr}$ recovered" cells responded with an $\mathrm{EC}_{50}$ of $0.8 \pm 0.3 \mu \mathrm{M}$, a 13-fold shift from the control $(p<0.005)$. At $24 \mathrm{hr}$ after agonist removal, cells

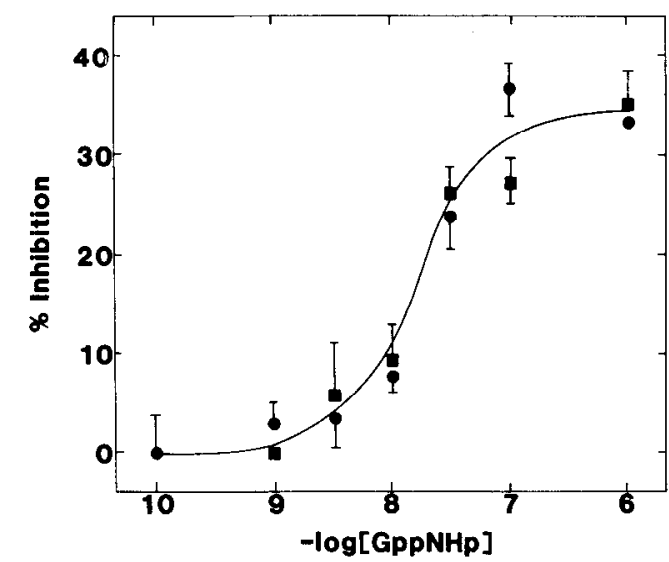

Figure 6. Inhibition of adenylate cyclase by GppNHp. Homogenates of cells grown in $100 \mathrm{~mm}$ dishes were assayed for the inhibition of adenylate cyclase by varying concentrations of GppNHp in the presence of $100 \mu \mathrm{M}$ forskolin, as described in Methods. (0), Control; (G), $18 \mathrm{hr}$ recovered. Maximal forskolin-stimulated activities were $1992 \pm 76$ (mean \pm standard deviation) and $2056 \pm 40$ pmol cAMP generated/ $10 \mathrm{~min} / \mathrm{mg}$ protein for control and $18 \mathrm{hr}$ recovered cells, respectively. Error bars show standard deviations for a single experiment, which is representative of 3 such experiments.

were at least as sensitive as control cells, responding with an $\mathrm{EC}_{50}$ of $31 \pm 13 \mathrm{nM}$ (significantly different from $18 \mathrm{hr}$ recovered cells: $p<0.0025$; not different from control cells: $p>0.05$ ). Since new protein synthesis was required for the recovery of $\mathrm{mAChR}$ number, we determined whether it was also required for the shift in sensitivity seen after receptor number had reached control values. Cells treated with carbachol for $6 \mathrm{hr}$ and allowed to recover for $18 \mathrm{hr}$ were treated with $20 \mu \mathrm{M}$ cycloheximide for $6 \mathrm{hr}$ to block further protein synthesis. Figure 3, bottom, shows the response to carbachol in these cells; the $\mathrm{EC}_{50}$ for carbachol was $20 \pm 10 \mathrm{nM}$, not significantly different from control $(p>$ $0.05)$ or $24 \mathrm{hr}$ recovered $(p>0.025)$. Thus the increase in sensitivity seen after $\mathrm{mAChR}$ number has returned to the control level does not require further de novo protein synthesis. This result is in agreement with results obtained in vivo (Hunter and Nathanson, 1984), which showed a similar increase in sensitivity in the negative chronotropic response of isolated atria following recovery from agonist-induced decreases in receptor number. The increase in physiological sensitivity in vivo was also not blocked by treatment with cycloheximide.

\section{Ligand binding to newly synthesized receptors}

To establish whether this decreased sensitivity was due to a decreased affinity of $\mathrm{mAChR}$ for muscarinic ligands, we studied the affinities of $\mathrm{mAChR}$ for muscarinic antagonists and agonists. Scatchard analysis of ${ }^{3} \mathrm{H}-\mathrm{NMS}$ binding to intact cells yielded similar dissociation constants for control and $18 \mathrm{hr}$ recovered cells ( 0.12 and $0.17 \mathrm{~nm}$, respectively; data not shown). To determine whether the decreased sensitivity was due to decreased affinity for carbachol, the carbachol affinities of $\mathrm{MAChR}$ were cxamined from ${ }^{3} \mathrm{H}-\mathrm{QNB}-$ carbachol competition binding studies in membrane homogenates. As guanyl nucleotides regulate the binding of agonists to $\mathrm{mAChR}$, we measured the binding of carbachol to $\mathrm{mAChR}$ in the presence and absence of the nonhydrolyzable GTP derivative guanosine $5^{\prime}[\beta, \gamma$-imido] triphosphate (GppNHp). As is shown in Figure 4, the binding of agonist to control and $18 \mathrm{hr}$ recovered homogenates was virtually identical.

\section{Inhibition of adenylate cyclase}

To conduct an independent biochemical assay of $\mathrm{mAChR}$ function, we tested for the sensitivity of $\mathrm{mAChR}$-mediated inhibi- 


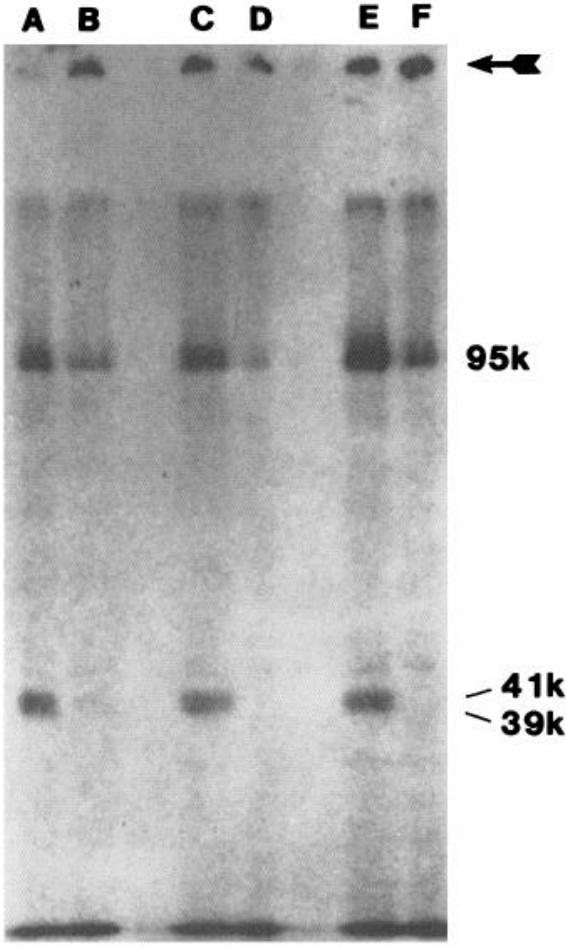

Figure 7. Autoradiograph of SDS-polyacrylamide gel of ADP-ribosylated membrane proteins. Membranes from cells grown in $100 \mathrm{~mm}$ dishes were incubated with ${ }^{32} \mathrm{P}-\mathrm{NAD}$ with (lanes $A, C$, and $E$ ) and without (lanes $B, D$, and $F$ ) pertussis toxin, as described in Methods. Lanes $A$ and $B$, membranes from control cells; lanes $C$ and $D$, membranes from $18 \mathrm{hr}$ recovered cells; lanes $E$ and $F$, membranes from 24 $\mathrm{hr}$ recovered cells. The band at 95,000 is nonspecifically labeled by incubation with ${ }^{32}$ P-NAD in the absence of pertussis toxin. The arrow indicates the top of the stacking gel.

tion of $\beta$-adrenergically stimulated adenylate cyclase in membrane homogenates from control, $18 \mathrm{hr}$ recovered, and $24 \mathrm{hr}$ recovered cells. This provided an assay for $\mathrm{mAChR}$ function in a cell-free membrane preparation in which only a few discrete components were involved: $\beta$-adrenergic receptor, stimulatory subunit of adenylate cyclase $\left(\mathrm{N}_{\mathrm{s}} ; 45 \mathrm{kDa}\right.$ cholera toxin substrate), $\mathrm{mAChR}$, inhibitory subunit of adenylate cyclase $\left(\mathrm{N}_{\mathrm{i}} ; 41 \mathrm{kDa}\right.$ pertussis toxin substrate), and catalytic subunit of adenylate cyclase. Figure 5 shows concentration-effect curves for the inhibition of adenylate cyclase by carbachol in control, $18 \mathrm{hr}$ recovered, and $24 \mathrm{hr}$ recovered homogenates. The $\mathrm{IC}_{50}$ for 18 $\mathrm{hr}$ recovered homogenates is 50 -fold higher than the control $(1.0 \pm 0.2 \mu \mathrm{M}$ vs $20 \pm 4 \mathrm{nM}$; significantly different, $p<0.0005)$, similar to the decreased sensitivity seen in the stimulation of $\mathrm{Rb}^{+}$efflux. The sensitivity of the inhibition of adenylate cyclase recovers by $24 \mathrm{hr}$ after agonist removal, however; $24 \mathrm{hr}$ recovered homogenates and control homogenates exhibit equal sensitivity to carbachol $\left(\mathrm{IC}_{50}\right.$ for $24 \mathrm{hr}$ recovered homogenates is $9.3 \pm 2.7 \mathrm{~nm} ; p>0.05$ ). All 3 groups exhibit similar maximal $\mathrm{mAChR}$-mediated inhibition of adenylate cyclase when tested simultaneously: $26.0 \pm 3.7 \%$ for control, $29.7 \pm 1.4 \%$ for 18 $\mathrm{hr}$ recovered, and $23.0 \pm 4.7 \%$ for $24 \mathrm{hr}$ recovered. The increased sensitivity for adenylate cyclase inhibition between 18 and $24 \mathrm{hr}$ following agonist removal, as for the increased sensitivity for $\mathrm{Rb}^{+}$efflux, is not blocked by administration of cycloheximide.

To examine whether the decreased sensitivity seen for adenylate cyclase inhibition was due to an altered guanyl nucleotide binding protein, we measured the activity of $\mathrm{N}_{\mathrm{i}}$ independent of receptor-mediated enzyme inhibition by assessing the ability of

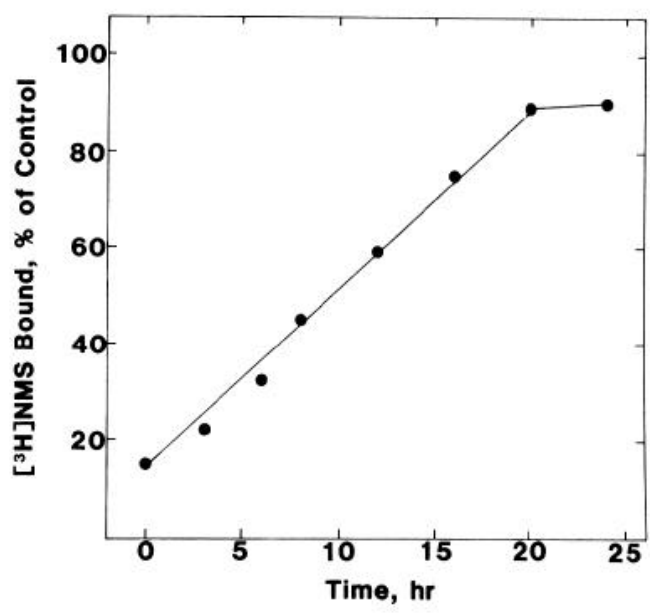

Figure 8. Time course of recovery of surface mAChR binding sites following affinity alkylation with PrBCM. Cells in $35 \mathrm{~mm}$ dishes were treated with $2 \mathrm{nM}$ PrBCM for $15 \mathrm{~min}$, washed, and incubated in fresh culture medium for the times shown. ${ }^{3} \mathrm{H}-\mathrm{NMS}$ binding was performed as described in Methods, and is plotted as the average of 2 such experiments. Similar results were obtained a total of 5 times.

GppNHp to inhibit forskolin-stimulated adenylate cyclase activity. GppNHp binds to $\mathrm{N}_{\mathrm{i}}$ more rapidly than to $\mathrm{N}_{\mathrm{s}}$ and thus, with the brief assay times used here (preincubation is required in order to see the stimulation of adenylate cyclase given by GppNHp alone; Seamon and Daly, 1982), it is possible to detect inhibition via $\mathrm{N}_{\mathrm{i}}$. Figure 6 shows that there is no difference in the sensitivity of inhibition of adenylate cyclase by GppNHp in control and in $18 \mathrm{hr}$ recovered homogenates. Thus, the activity of $\mathrm{N}_{\mathrm{i}}$ in cells exhibiting decreased sensitivity to muscarinic agonists appears to be the same as that in control cells.

Pertussis toxin catalyzes the ADP ribosylation of 2 membrane proteins in chick heart (Halvorsen and Nathanson, 1984), termed $\mathrm{N}_{0 \alpha}$ and $\mathrm{N}_{\mathrm{i} \alpha}$, which are the $\alpha$-subunits of the heterotrimeric proteins $\mathrm{N}_{0}$ and $\mathrm{N}_{\mathrm{i}}\left(\mathrm{N}_{0}=39 \mathrm{kDa}\right.$ pertussis toxin substrate). These 2 proteins differ in their peptide maps (Martin et al., 1985), are immunologically distinct (C. W. Luetje and N. M. Nathanson, unpublished observations), and are analogous to the proteins termed $\mathrm{G}_{0 \alpha}$ and $\mathrm{G}_{\mathrm{i} \alpha}$ in brain (Sternweis and Robishaw, 1984). $G_{0 \alpha}$ from brain, although capable of interacting with $\mathrm{mAChR}$ in producing GTP effects on agonist binding (Florio and Sternweis, 1985), does not reconstitute mAChR-mediated inhibition of adenylate cyclase activity (Roof et al., 1985). $\mathrm{G}_{\mathrm{i} \alpha}$ from brain can serve in both functions. Figure 7 shows ADPribosylated membranes from control, $18 \mathrm{hr}$ recovered, and 24 $\mathrm{hr}$ recovered cells that were solubilized and subjected to SDSgel electrophoresis. Labeled polypeptides at 41,000 $\mathrm{Da}$ and $39,000 \mathrm{Da}$ correspond to $\mathrm{N}_{\mathrm{i} \alpha}$ and $\mathrm{N}_{0 \alpha}$, respectively. There is no significant difference in the labeling among the conditions. Twodimensional gel electrophoresis of proteins that were ADP-ribosylated in the presence of pertussis toxin also showed no significant differences in $\mathrm{N}_{\mathrm{i} \alpha}$ and $\mathrm{N}_{0 \alpha}$ from control, $18 \mathrm{hr}$ recovered, and $24 \mathrm{hr}$ recovered homogenates (not shown). The lack of differences in $\mathrm{N}_{\mathrm{i} \alpha}$ among these conditions is in agreement with the similar $\mathrm{IC}_{50} \mathrm{~s}$ observed for the inhibition of adenylate cyclase by GppNHp, and suggests that $\mathrm{N}_{\mathrm{i}}$ is not the component in the transduction system whose alteration results in decreased sensitivity.

\section{Responsiveness of cardiac cells containing receptors that} reappear following affinity alkylation

We wished to investigate the decreased sensitivity seen in cells containing receptors that recovered following agonist exposure, and to discover whether this was due simply to nonspecific 


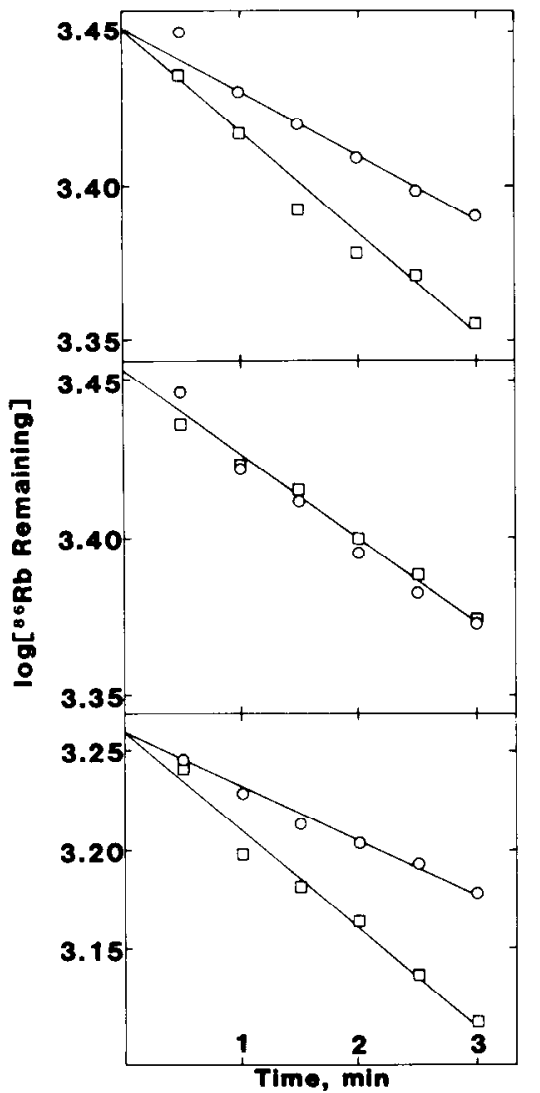

Figure 9. Stimulation of $\mathbf{R b}^{+}$efflux by carbachol. Cells cultured in Hyclonc fetal bovine serum, lot 1114574 , were loaded with ${ }^{86} \mathrm{Rb}^{+}$and efflux was followed, as described in Methods. Top, Control. At $t=0$, fresh medium was added with no addition $(O)$, or with $0.1 \mathrm{~mm}$ carbachol ( $\square$ ). Correlation coefficients for these lines were 0.986 and 0.982 . Center Cells were treated with $5 \mathrm{nM} \operatorname{PrBCM}$ for $15 \mathrm{~min}$ at $37^{\circ} \mathrm{C}$, washed, and allowed to recover for $18 \mathrm{hr}$. At $t=0$, fresh medium was added with no addition $(O)$, or with $0.1 \mathrm{~mm}$ carbachol $(\square)$. Correlation coefficients for these lines were 0.989 and 0.990 . Bottom, Cells were treated with $5 \mathrm{nM} \operatorname{PrBCM}$ for $15 \mathrm{~min}$ at $37^{\circ} \mathrm{C}$, washed, and allowed to recover for $24 \mathrm{hr}$. At $t=0$, fresh medium was added with no addition $(O)$, or with $0.1 \mathrm{~mm}$ carbachol $(\square)$. Correlation coefficients for these lines were 0.994 and 0.992 .

effects resulting from the agonist exposure itself. We therefore measured the responsiveness in cells that contained receptors that appear following treatment with PrBCM. Treatment of cardiac cells with the irreversible antagonist $\operatorname{PrBCM}(1 \mathrm{nM})$ for 15 min results in the alkylation of $85-100 \%$ of receptors, as determined by the loss of specific binding of ${ }^{3} \mathrm{H}-\mathrm{NMS}$. Removal of PrBCM results in a gradual increase in receptor number, which reaches the control level 20-24 hr after PrBCM removal (Fig. 8). This time course is somewhat slower than that seen after agonist-induced down-regulation (see Discussion). The recovery of receptor number is blocked by the administration of $20 \mu \mathrm{M}$ cycloheximide (not shown), suggesting that the receptors that appear following affinity alkylation, like those that appear following agonist-induced decreases, are newly synthesized proteins.

Figure 9 shows the stimulation of $\mathrm{Rb}^{+}$efflux from individual wells of cardiac cells that were treated with PrBCM for $15 \mathrm{~min}$, washed, and allowed to recover for the given times. Representative control cells, shown in Figure 9 (top), exhibited a decrease for efflux in $t_{1 / 2}$ from 11.7 to $8.5 \mathrm{~min}$ in the presence of $0.1 \mathrm{~mm}$ carbachol. At $18 \mathrm{hr}$ after PrBCM treatment, at which time cells contained $80-85 \%$ of the control level of $\mathrm{mAChR}$, there was no

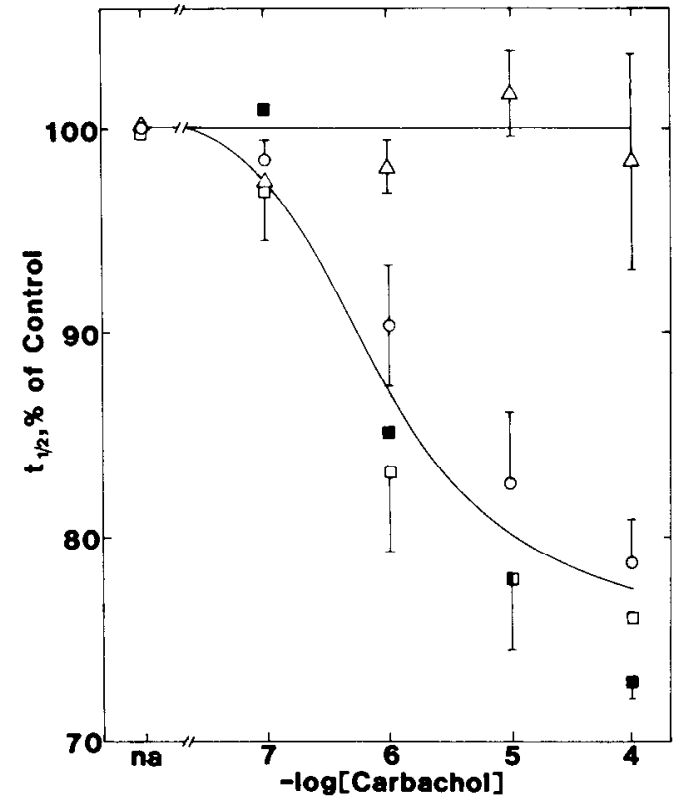

Figure 10. Concentration-effect curves for carbachol-mediated stimulation of $\mathrm{Rb}^{+}$efflux following recovery from affinity alkylation. Increasing concentrations of carbachol were added to triplicate wells at $t=0$, and half-times of efflux were determined, as described in Methods. Cells were cultured in Gibco fetal bovine serum lot $31 \mathrm{~K} 8843$ and Hyclone fetal bovine serum lot 1114574 . $(O)$, Control cells; $(\triangle)$, cells at 18 $\mathrm{hr}$ after PrBCM alkylation; ( $\square$ ), cells at $24 \mathrm{hr}$ after PrBCM alkylation; (D), cells that were treated with $\operatorname{PrBCM}$, allowed to recover for $18 \mathrm{hr}$, were then treated with $20 \mu \mathrm{M}$ cycloheximide, and allowed to recover for 6 additional hr. Error bars show the SEM for at least 3 independent experiments for each group.

response to $0.1 \mathrm{mM}$ carbachol (Fig. 9, center); at $24 \mathrm{hr}$ after PrBCM treatment, cells responded with a reduction in $t_{1 / 2}$ from 10.9 to $6.1 \mathrm{~min}$ in the presence of $0.1 \mathrm{~mm}$ carbachol (Fig. 9, bottom). Figure 10 compares the concentration-effect curves for the stimulation of $\mathrm{Rb}^{+}$efflux. (The lot of serum used for cell culture in these experiments did not permit coupling of $\mathrm{mAChR}$ to $\mathrm{Rb}^{+}$efflux in control cells as efficient as the serum used for the experiments shown in Fig. 3, which caused a decrease in the spare receptor reserve and a corresponding shift in the doseresponse curve as compared to those of the control cultures shown in Fig. 3.) No response is seen at $18 \mathrm{hr}$ after PrBCM treatment, but at $24 \mathrm{hr}$, the $\mathrm{IC}_{50}$ for carbachol $(0.8 \pm 0.5 \mu \mathrm{M})$ is similar to that for the control $(1.7 \pm 0.8 \mu \mathrm{M}$; not significantly different, $p>0.05$ ). The increase in sensitivity that occurs between 18 and $24 \mathrm{hr}$ is not blocked by cycloheximide. This result is consistent with the increase in sensitivity following recovery of receptor number after agonist exposure. Thus, the decreased sensitivity seen in cells containing $\mathrm{MAChR}$ that recover following agonist exposure is not due to metabolic consequences of the agonist exposure itself, but is rather an innate property of newly synthesized $\mathrm{mAChR}$ or one of its coupling proteins.

\section{Physical properties of newly synthesized $m A C h R$}

To determine whether there were any major physical differences between newly synthesized and "mature" receptors, we examined the molecular weight and isoelectric point of $\mathrm{MAChR}$ in cells exhibiting each type of response. Large et al. (1985a, b) have shown different molecular weights and isoelectric points during different stages of development in chicken retina; these changes in molecular properties were correlated with the onset of synaptogenesis and with stabilization of the receptor. Figure 11 shows representative SDS-gel profiles for solubilized cells 


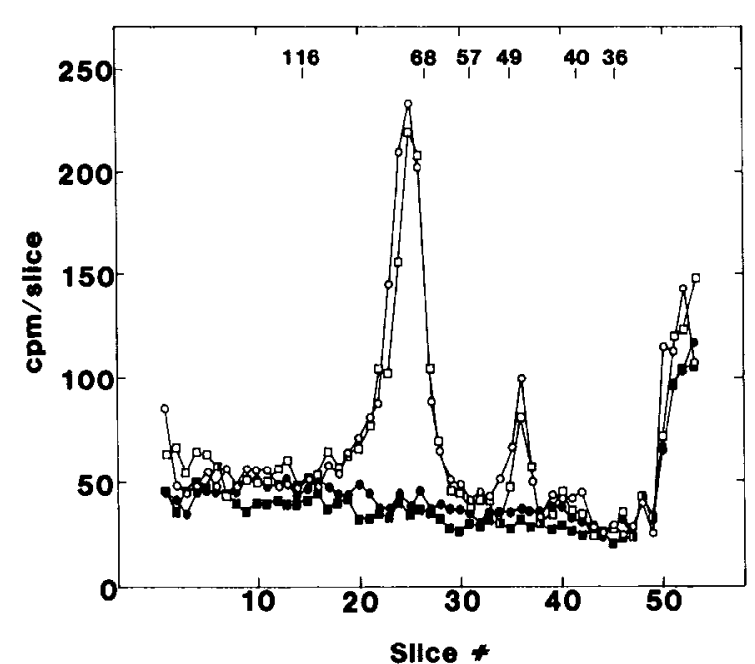

Figure 11. SDS-urea gel profiles for ${ }^{3} \mathrm{H}-\mathrm{PrBCM}$-labeled proteins. Cells grown in $100 \mathrm{~mm}$ dishes were labeled with ${ }^{3} \mathrm{H}-\mathrm{PrBCM}$, solubilized, and subjected to electrophoresis, as described in Methods. Lanes from 3-mmthick, $7.5 \%$ acrylamide slab gels were sliced into $3 \mathrm{~mm}$ sections, and radioactivity in each slice was determined as described in Methods. $(O)$, Control cells; ( $\square$ ), $18 \mathrm{hr}$ recovered cells. Filled symbols are the radioactivity present in each slice following alkylation in the presence of 10 $\mu \mathrm{M}$ atropine. This experiment was performed 5 times with similar results.

that had been labeled with ${ }^{3} \mathrm{H}-\mathrm{PrBCM}$. There is no significant difference in molecular weight between the ${ }^{3} \mathrm{H}-\mathrm{PrBCM}$-labeled protein from control and $18 \mathrm{hr}$ recovered cells; a major peak of radioactivity, corresponding to a molecular weight of 74,000 , is seen in both cases. This value is in agreement with the molecular weight reported by other groups for a wide variety of tissues. There is also a small amount of a smaller, specifically labeled polypeptide present in both cases, with a molecular weight of 48,000 . The relative amount of this protein varies from experiment to experiment, and it is the predominant form when cells are homogenized prior to solubilization (see Methods), suggesting that the lower-molecular-weight species is a product of degradation of the mAChR.

Figure 12 shows representative isoelectric focusing gel profiles for solubilized cells that had been labeled with ${ }^{3} \mathrm{H}-\mathrm{PrBCM}$. For both control and $18 \mathrm{hr}$ recovered cells, a single major peak of radioactivity is observed, corresponding to a pI of 5.8. This technique is capable of resolving differences in isoelectric points of 0.05 , corresponding to several charge differences. Thus, there do not seem to be covalent modifications detectable at this level of resolution that underlie the difference between newly synthesized and "mature" mAChR.

\section{Discussion}

We have used 2 different methods to reduce muscarinic receptor binding sites on the surface of cardiac cells: agonist-induced receptor loss, and alkylation of receptors with PrBCM. Binding sites that reappear on the surface of cardiac cells in culture after such treatments, and which presumably are newly synthesized receptors, are poorly coupled to the stimulation of $\mathrm{Rb}^{+}$efflux from these cells. Cells containing these receptors slowly become more sensitive to muscarinic agonists; this conversion to the more active state does not require de novo protein synthesis, and is consistent with a maturation of the receptor or a closely linked protein.

Membranes from cells containing receptors that are synthesized following agonist-induced decreases in receptor number also show a decreased sensitivity in the inhibition of adenylate cyclase by carbachol. Recovery of sensitivity in the inhibition

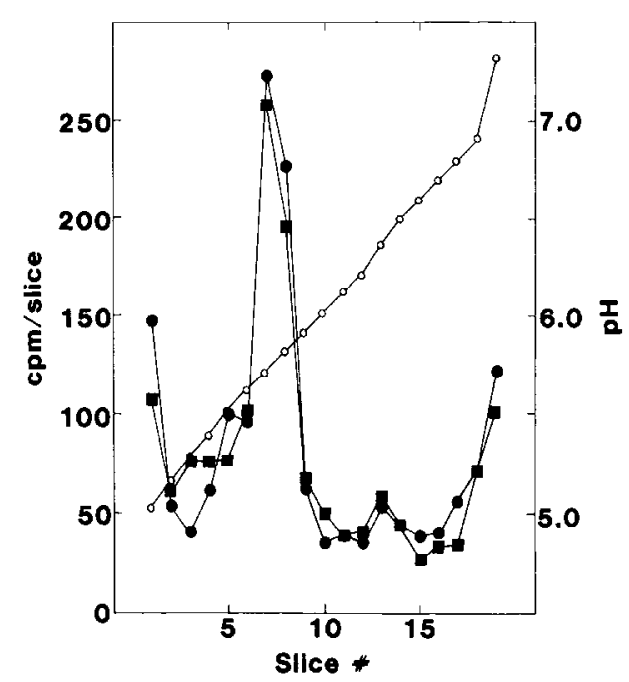

Figure 12. Isoelectric focusing gel profiles for ${ }^{3} \mathrm{H}-\mathrm{PrBCM}$-labeled proteins. Cells grown in $100 \mathrm{~mm}$ dishes were labeled with ${ }^{3} \mathrm{H}-\mathrm{PrBCM}$, solubilized, focused, and sliced into $5 \mathrm{~mm}$ sections, as described in Methods. (O), Control cells; ( $\square$ ), $18 \mathrm{hr}$ recovered cells. The average $\mathrm{pH}$ gradient in 2 parallel tube gels is also shown (O). No radioactivity was observed at pI 5.8, when alkylation was performed in the presence of $10 \mu \mathrm{M}$ atropine. This experiment was performed 7 times with similar results.

of adenylate cyclase follows a time course similar to that for recovery of sensitivity in the stimulation of $\mathrm{Rb}^{+}$efflux. These findings are similar to those previously reported for atria in vivo (Hunter and Nathanson, 1984) and to those reported by Taylor et al. (1979), which showed a lag in recovery of mAChR-mediated cGMP synthesis following the recovery of $\mathrm{mAChR}$ number in mouse neuroblastoma cells. These results are different from those of Galper et al. (1982b), however, who reported no change in responsiveness for $\mathrm{mAChR}$-mediated increases in $\mathrm{K}^{+}$ efflux following recovery from agonist-induced receptor loss. This discrepancy is probably due to the different assay conditions used: Galper et al. (1982b) assayed function at a single, high carbachol concentration ( $1 \mathrm{mM}$ ); we also see no difference in receptor function at this concentration of carbachol (Fig. 3).

The number of receptors present on the surface of the cell increases with the same time course as the number of total cellular receptors, eliminating the possibility that the decreased sensitivity was due to an intracellular pool of receptors that had not yet been transported to the membrane. Cells containing newly synthesized receplors bind agonists and antagonists with affinities similar to those for control cells, which eliminates the possibility that the decreased sensitivity was due to decreased affinities for muscarinic ligands. Guanyl nucleotide binding proteins appear to be unchanged in cells containing newly synthesized receptors, indicating that the insensitivity seen in cells containing newly synthesized $\mathrm{mAChR}$ is not analogous to the decreased physiological responsiveness of 3-4 d embryonic chicken atria, which is associated with alterations in the physical properties of $\mathrm{N}_{\mathrm{i}}$ and $\mathrm{N}_{\mathrm{o}}$ (Halvorsen and Nathanson, 1984). Thus, since the pathway for inhibition of adenylate cyclase presumably contains only 3 components (receptor, $N_{i}$, and catalytic subunit), the most likely location of an alteration is the muscarinic receptor itself. Although we have not determined the relative contributions of $\mathrm{N}_{\mathrm{i} \beta}$ and $\mathrm{N}_{0 \beta}$ to the decreased sensitivity, the absence of a functional difference, as shown in Figure 6, argues against a significant alteration of the $\beta$-subunits.

Receptors that appear following affinity alkylation of surface receptors with PrBCM, like those that appear following agonistinduced receptor loss, are poorly coupled to the mAChR-me- 
diated increase in potassium permeability. Thus, the decreased sensitivity seen in cells containing newly synthesized mAChR is not due to an alteration in cellular metabolism caused by long-term agonist exposure. The time course of recovery of receptor number following PrBCM alkylation is somewhat slower than that for recovery following agonist-induced decreases, however. This suggests that either the rate of synthesis or degradation (or both) of $\mathrm{mAChR}$ following recovery from agonist treatment is different than the rate(s) following recovery from PrBCM treatment. A full investigation of this phenomenon would require experiments using either metabolic-labeling (as for the nicotinic acetylcholine receptor; Merlie et al., 1982) or densityshift (also as for the nicotinic receptor; Devreotes et al., 1977) techniques to directly measure the kinctics of synthesis and degradation of $\mathrm{MAChR}$.

Comparison of the biochemical properties of newly synthesized and mature receptors indicates that the change in sensitivity of receptor-mediated responses is not due to major changes in either the pI or molccular weight of the receptors. The solubilization of $\mathrm{mAChR}$ in digitonin results in a preparation with a pI of 4.2-4.6 (Large et al., 1985a; Repke and Matthies, 1980). More stringent solubilization conditions, such as initial solubilization in SDS, are commonly used for the extraction of intrinsic membrane proteins prior to isoelectric focusing. Using such a technique, Venter et al. (1984) reported a pl of ca. 5.9 for $\mathrm{mAChR}$ from a variety of tissues, including human brain, canine heart, and Drosophila head. The most consistent results we have obtained have been with an NP-40-urea solubilization, followed by isoelectric focusing in urea, which results in a $\mathrm{pI}$ of 5.8 , similar to that seen by Venter et al. (1984). A much lower yield of receptor can be solubilized and focused in digitonin; when this is done, a pI of 4.5 is seen (data not shown). This difference in pI may reflect the cosolubilization of associated proteins in one case and not the other, increased stability upon solubilization in one of the detergents, or aggregation under the less stringent conditions of digitonin solubilization.

Large et al. (1985a, b) have recently reported several developmental changes in $\mathrm{mAChR}$ properties in chicken retina. The molecular weight of the receptor, determined using a procedure similar to the one employed here, changed from predominantly 86,000 to predominantly 72,000 , and the isoelectric point from 4.25 to 4.5 during development from embryonic day 12 to adult. The results reported here show no change in receptor molecular weight or isoelectric point during the increase in sensitivity following recovery of receptor number. Thus, the molecular basis for the shift in sensitivity to muscarinic agonists must be either a small change in the $\mathrm{MAChR}$ or a change in an as-yet-undefined component of the $\mathrm{mAChR}$ transduction system. We have recently begun reconstitution studies, using purified GTP-binding proteins and purified $\mathrm{mAChR}$, in an attempt to identify the location of this change. This system will be useful in defining the roles such alterations can play in the modulation of cholinergic signals in the heart.

\section{References}

Ames, G. F.-L., and K. Nikaido (1976) Two-dimensional gel electrophoresis of membrane proteins. Biochemistry 18: 616-623.

DeHaen, R. L. (1967) Regulation of spontaneous activity and growth of embryonic chick heart cells in tissue culture. Dev. Biol. 16:216249.

Devreotes, P. N., J. M. Gardner, and D. M. Fambrough (1977) Kinetics of biosynthesis of acetylcholine receptor and subsequent incorporation into plasma membrane of cultured chick skeletal muscle. Cell 10: 365-373.

Florio, V. A., and P. C. Sternweis (1985) Reconstitution of resolved muscarinic cholinergic receptors with purified GTP-binding proteins. J. Biol. Chem. 260: 3477-3483.

Galper, J. B., and T. W. Smith (1980) Agonist and guanine nucleotide modulation of muscarinic cholinergic receptors in cultured heart cells. J. Biol. Chem. 255: 9571-9579.

Galper, J. B., L. C. Dziekan, D. S. O'Hara, and T. W. Smith (1982a) The biphasic response of muscarinic cholinergic receptors in cultured heart cells to agonists: Effects on receptor number and affinity in intact cells and homogenates. J. Biol. Chem. 257: 10344-10356.

Galper, J. B., L. C. Dzickan, D. S. Miura, and T. W. Smith (1982b) Agonist-induced changes in the modulation of $\mathrm{K}$ permeability and beating rate by muscarinic agonists in cultured heart cells. J. Gen. Physiol. 80: 231-256.

Halvorsen, S. W., and N. M. Nathanson (1981) In vivo regulation of muscarinic acetylcholine receptor number and function in embryonic chick heart. J. Biol. Chem. 256: 7941-7948.

Halvorsen, S. W., and N. M. Nathanson (1984) Ontogenesis of physiological responsiveness and guanine nucleotide sensitivity of cardiac muscarinic receptors during chick embryonic development. Biochemistry 23: $5813-5821$

Harden, T. K., L. A. Petch, S. F. Trayneslis, and G. L. Waldo (1985) Agonist-induced alteration in the membrane form of muscarinic cholinergic receptors. J. Biol. Chem. 260: 13060-13066.

Hunter, D. D., and N. M. Nathanson (1984) Decreased physiological sensitivity mediated by newly synthesized muscarinic acetylcholine receptors in embryonic chick heart. Proc. Natl. Acad. Sci. USA 81 3582-3586.

Hunter, D. D., and N. M. Nathanson (1985) Assay of muscarinic acetylcholine receptor function in cultured cardiac cells by stimulation of ${ }^{86} \mathrm{Rb}^{+}$efflux. Anal. Biochem. 149: 392-398.

Inoue, D., M. Hachisu, and A. J. Pappano (1983) Acetylcholine increases resting membrane potassium conductance in atrial but not in ventricular muscle during muscarinic inhibition of $\mathrm{Ca}$ dependent action potentials in chick heart. Circ. Res. 53: 158-167.

Klein, W. L., N. Nathanson, and M. Nirenberg (1979) Muscarinic acetylcholine receptor regulation by accelerated rate of receptor loss. Biochem. Biophys. Res. Commun. 90: 506-512.

Laemmli, U. K. (1970) Cleavage of structural protcins during the assembly of the head of bacteriophage T4. Nature 227: 680-685.

Large, T. H., N. J. Cho, F. G. DeMello, and W. L. Klein (1985a) Molecular alteration of a muscarinic acelylcholine receptor system during synaptogenesis. J. Biol. Chem. 260: 8873-8881.

Large, T. H., J. J. Rauh, F. G. De Mello, and W. L. Klein (1985b) Two molecular forms of muscarinic acetylcholine receptors in the avian central nervous system. Proc. Natl. Acad. Sci. USA 82: 8785 8789.

Liles, W. C., and N. M. Nathanson (1986) Regulation of neuronal muscarinic acetylcholine receptor number by protein glycosylation. J. Neurochem. 46: 89-95.

Lowry, O. H., N. J. Rosenbrough, A. L. Farr, and R. J. Randall (1951) Protein measurement with the Folin phenol reagent. J. Biol. Chem. 193: 265-275.

Martin, J. M., D. D. Hunter, and N. M. Nathanson (1985) Islet activating protein inhibits physiological responses evoked by cardiac muscarinic acetylcholine receptors. Role of GTP-binding proteins in regulation of potassium permeability. Biochemistry $24: 7521-7525$.

Merlie, J. P., R. Sebbane, S. Tzartos, and J. Lindstrom (1982) Inhibition of glycosylation with tunicamycin blocks assembly of newly synthesized acetylcholine receptor subunits in muscle cells. J. Biol. Chem. 257: 2694-2701.

Meyer, M. R., M. W. Gainer, and N. M. Nathanson (1982) In vivo regulation of muscarinic cholinergic receptors in embryonic chick brain. Mol. Pharmacol. 21: 280-286.

Nathanson, N. M. (1983) Binding of agonists and antagonists to muscarinic acetylcholine receptors on intact cultured heart cells. J. Neurochem. 41: 1545-1549.

Nathanson, N. M., and Z. W. Hall (1979) Subunit structure and peptide mapping of junctional and extrajunctional acetylcholine receptors from rat muscle. Biochemistry 18: 3392-3401.

Repke, H., and H. Matthies (1980) Biochemical characterization of solubilized muscarinic acetylcholine receptors. Brain Res. Bull. 5: 703-709.

Roof, D. J., M. L. Applebury, and P. C. Sternweis (1985) Relationships within the family of GTP-binding proteins isolated from bovine central nervous system. J. Biol. Chem. 260: 16242-16249.

Sakmann, B., A. Noma, and W. Trautwein (1983) Acetylcholine activation of single muscarinic $\mathrm{K}$ channels in isolated pacemaker cells of the mammalian heart. Nature 303: 250-253. 
Seamon, K. B., and J. W. Daly (1982) Guanosine $5^{\prime}$-( $\beta, \gamma$-imido)triphosphate inhibition of forskolin-activated adenylate cyclase is mediated by the putative inhibitory guanine nucleotide regulatory protein. J. Biol. Chem. 257: 11591-11596.

Shifrin, G. S., and W. L. Klein (1980) Regulation of muscarinic acetylcholine receptor concentration in cloned neuroblastoma cells. J. Neurochem. 34: 993-999.

Sternweis, P. C., and J. D. Robishaw (1984) Isolation of two proteins with high affinity for guanine nucleotides from membranes of bovine brain. J. Biol. Chem. 259: 13806-13813.

Taylor, J. E., E. El-Fakahany, and E. Richelson (1979) Long-termregulation of muscarinic acetylcholine receptors on cultured nerve cells. Life Sci. 25: 2181-2187.
Trautwein, W., and J. Dudel (1958) Zum Mechanismus der Membranwirkung des Acetylcholin an der Herzmuskelfaser. Phuegers Arch. 266: 324-334.

Venter, J. C., B. Eddy, L. M. Hall, and C. M. Fraser (1984) Monoclonal antibodies detect the conservation of muscarinic cholinergic receptor structure from Drosophila to human brain and detect possible structural homology with $\alpha_{1}$-adrenergic receptors. Proc. Natl. Acad. Sci. USA 81: 272-276.

Vlasuk, G. P., and F. G. Walz, Jr. (1980) Liver endoplasmic reticulum polypeptides resolved by two-dimensional gel electrophoresis. Anal. Biochem. 105: 112-120.

Yamamura, H. I., and S. H. Snyder (1974) Muscarinic cholinergic binding in rat brain. Proc. Natl. Acad. Sci. USA 71: 1725-1729. 